\title{
INCIDENCE OF CARDIOVASCULAR RISK FACTORS IN OBESE CHILDREN
}

\author{
Lidija Rakočević ${ }^{1}$ and Velimir Rakočević ${ }^{2}$ \\ ${ }^{1}$ Institute for Childhood Diseases, Clinical Centre of Montenegro; \\ ${ }^{2}$ University of Montenegro, Podgorica, Montenegro
}

\begin{abstract}
SUMMARY - The aim of the study was to determine the prevalence of metabolic syndrome factors in obese children by examining blood pressure, lipid status, disorders of glycoregulation, and parameters of insulin sensitivity and secretion. The survey was conducted as a cross sectional study. We analyzed the results of obese children aged 7 to 16 years visiting Clinical Centre of Montenegro during the 2011-2015 period. Out of 173 children with elevated body mass index, 119 (68.8\%) children were overweight, while first-degree obesity was recorded in 50 (28.9\%) and second-degree obesity in four (2.3\%) children. High blood pressure was found in $35.2 \%$, elevated cholesterol levels in $9.8 \%$ and elevated triglyceride levels in $8.09 \%$ of obese children. Oral glucose load testing revealed disturbing fasting glycemia in $4.76 \%$ and impaired glucose tolerance in $19.04 \%$ of obese children. High values of insulinemia two hours after glucose load were recorded in $35 \%$ of obese children. Study results showed the prevalence of risk factors for cardiovascular diseases and metabolic disorders, especially carbohydrates and fat, to be very high in our population of obese children. This imposes the need of changing current mode of assessing dietary habits during general medical examinations, as well as to start recording and monitoring overweight children and those with pronounced obesity.
\end{abstract}

Key words: Metabolic syndrome X; Pediatric obesity; Risk factors; Prevalence

\section{Introduction}

Metabolic syndrome takes one of the key positions in contemporary medicine research because of significant increase in the rate of morbidity of cardiovascular diseases. Most authors accept the recommendations for diagnosing metabolic syndrome, according to which the basic elements of the syndrome are central type of obesity, insulin resistance and intolerance of glucose, atherogenic dyslipidemia and arterial hypertension ${ }^{1}$. In 2007, the International Diabetes Federation (IDF) defined the criteria for the risk of metabolic syndrome development in children with the intention to estimate the risk of diabetes mellitus type 2 (T2DM) and cardiovascular disease by early identification of the children at risk of metabolic syndrome

Correspondence to: Lidija Rakočević, MD, Clinical Centre of Montenegro, Podgorica, Montenegro

E-mail: 1rakocevic@t-com.me

Received May 19, 2015, accepted June 7, 2016 development. According to these criteria, the diagnosis of metabolic syndrome cannot be established at the age of 6-10 years. In this age group, additional monitoring is required if there is positive family history of metabolic syndrome, T2DM, cardiovascular diseases and dyslipidemia. The criteria for metabolic syndrome in children aged 10-16 years include waist obesity (waist circumference $\geq 90 \%$ or lower limit for adults, if lower), triglycerides $\geq 1.7 \mathrm{mmol} / \mathrm{L}$, high-density lipoprotein (HDL) cholesterol $<1.03 \mathrm{mmol} / \mathrm{L}$, glycemia $\geq 5.6 \mathrm{mmol} / \mathrm{L}$ or T2DM (if glycemia is $\geq 5.6 \mathrm{mmol} / \mathrm{L}$, oral glucose tolerance test (OGTT) should be done), systolic blood pressure $\geq 130 \mathrm{~mm} \mathrm{Hg}$ or diastolic $\geq 85$ $\mathrm{mm} \mathrm{Hg}$ ). In children older than 16 , we use the IDF criteria for adults.

The android type of obesity in childhood has been shown to imply greater risk of cardiovascular disease in adulthood than gynoid type. This has been demonstrated among children and adolescents by proving the association of visceral fat with high triglycerides and 
lowered HDL cholesterol, as well as high blood pressure. These consequences do not depend on the percentage of total body fat. The mechanism by which it results in a higher risk of cardiovascular disease and visceral fat increase has not yet been fully clarified but it is probably associated with insulin resistance, cortisol and adipocyte hormones ${ }^{2}$.

Reaven ${ }^{3}$ was the first to describe syndrome $\mathrm{X}$ in the context of association of metabolic risk factors and diseases. Reaven has formulated his concept of the syndrome on the basis of the potentially harmful effects of insulin resistance, describing it as "the lower takeover of glucose by the means of insulin". Current understanding of syndrome $\mathrm{X}$ implies its emergence from insulin resistance, while at the same time there is an increased risk of atherosclerotic disease and T2DM ${ }^{4}$. Hyperinsulinemia, the primary characteristic of syndrome $\mathrm{X}$, occurs as the result of increased resistance to the action of insulin, which is associated with insulin full depots. Insulin resistance impairs glucose disposal, thus sugar remains in the blood, along with excess of fat in the liver. Studies have shown that obese people have a higher risk of developing insulin resistance compared to thin people. Syndrome $\mathrm{X}$ is also known as a metabolic cardiovascular syndrome and atherothrombogenic syndrome ${ }^{5}$. It has been proven that metabolic syndrome emerges in childhood but is more pronounced in obese children. About 30\% of obese children have metabolic syndrome and 9 of 10 obese children have at least one component of the metabolic syndrome ${ }^{6}$.

Early detection of the risks that lead to the development of metabolic syndrome among children is very important for their later life. The syndrome is ever more present among children; the National Health and Nutrition Examination Survey ${ }^{7}$ found its prevalence to be $6.4 \%$ at the end of 2000 in comparison to $4.2 \%$ in 1992 ( $\mathrm{p}<0.001)$. By tracking disorders of glucose tolerance and insulin levels in obese children, in his doctoral dissertation Bojović ${ }^{8}$ stresses that obesity in childhood implies the risk of metabolic disturbance of carbohydrates and fat that might manifest as T2DM later in life. The author came to such a conclusion by comparing the results of a large survey of obese children $(\mathrm{N}=312)$ and normal weight children aged 7-14 years. On OGTT, the obese children had a statistically significantly greater disturbance of glucose tolerance (impaired glucose tolerance (IGT), 1.28\%) and base- line insulin levels $(15.8 \mathrm{IU} / \mathrm{mL})$ in comparison to agematched normal weight children that had normal glucose tolerance and baseline insulin levels (13.3 IU/ $\mathrm{mL}$ ). Also, it was found that the percentage of boys with higher free fatty acid level increased significantly with the increasing degree of obesity.

Atherosclerosis characterized by the blood vessel walls losing elasticity and muscle tissue being replaced by fibrous tissue and sometimes calcified plates, is the culmination of lipid deposition in damaged blood vessel walls throughout life, and not just over the last few years or only in old age. Atherosclerosis is in tight connection with metabolic lipid disturbance, although the impact of all other factors that damage blood vessel walls is indisputable, with special emphasis on hereditary factor that is transmitted from generation to generation.

Elevated concentration of cholesterol is of special importance in the development of atherosclerosis. The fat material, especially the cholesterol circulating through the blood vessels, is deposited in the walls of arterial blood vessels, in particular at the sites of their branching.

The high levels of low-density lipoprotein (LDL) cholesterol mainly and dominantly increase the risk of coronary disease. People with hereditary hypercholesterolemia who have deficiency of LDL receptors that implies inability of cholesterol breakdown are at risk of coronary disease. In the early process of atherogenesis, damaged cells pass through monocytes-macrophages and LDL is infiltrated in the subepithelial space. LDL that are oxidized by an unknown mechanism absorb the macrophages, forming the so-called foam cells. With further processes of the lesions, fat strips and accumulation of elastic tissues, proliferation of fibrin lesions, necrosis and foaming muscular cells and destruction of the layer that covers endothelial cells of induction and the formation of the thrombus and calcification, the atherogenesis process comes to an end. People with low levels of LDL cholesterol have prospects for a long life. Reduction of the LDL cholesterol level diminishes the atherosclerotic risk ${ }^{9}$. High-density lipoprotein is negatively correlated with cardiovascular disease. The protective effect of HDL cholesterol levels is demonstrated when the LDL is high ${ }^{10}$.

The prevalence of vascular diseases is also high in people with high triglyceride levels, especially hyperlipoproteinemia of inherited type. 
The aim of the study was to determine general and specific prevalence of the factors of metabolic syndrome among obese children. Evaluating the results, we want to point to the importance of metabolic syndrome in childhood for later development of cardiovascular and metabolic diseases.

\section{Subjects and Methods}

The survey was carried out in the form of a cross sectional study and analyzed children aged 7 to 16 years tested at Clinical Department of Endocrinology, Institute for Childhood Diseases of Montenegro in Podgorica during the period from February 14, 2011 to February 14, 2015. The survey included 173 obese children with high body mass index (BMI) values, divided into 3 groups as follows: overweight (BMI 25.029.9); first-degree obesity (BMI 30.0-34.9); seconddegree obesity (BMI 35.0-39.9); and third-degree obesity (BMI $\geq 40.0$ ).

For setting the diagnosis of metabolic syndrome, we used the IDF criteria from 2006. Waist size was measured by plasticized meter that cannot stretch. Waist size was expressed in centimeters with one decimal. Blood pressure was measured with a mercury manometer with cuff appropriate for each child's age. The levels of cholesterol, HDL cholesterol, LDL choles- terol and triglycerides were determined at Central Laboratory of the Clinical Centre in Podgorica. For cholesterol and its fractions, the enzymatic method of high specificity was employed. Triglycerides were determined by the enzymatic method with the appropriate test reagent. OGTT was performed according to the WHO diabetes criteria from 1999. The values of glycemia and insulin were determined in fasting state and 2 hours post-load with $1.75 \mathrm{~g}$ glucose per kilogram body weight. C-peptide was determined only in fasting state. Radioimmunoassay of insulin and C-peptide was performed in Radioisotope Laboratory of the Clinical Centre in Podgorica. Interpretation of glycemia value was based on the WHO recommendations from 1999. The sample for lipid status monitoring included 173 obese children. The sample for glycemia monitoring, insulin and C-peptide during OGTT included 21 obese children randomly selected among 173 obese children (12.1\%).

\section{Results}

Out of 173 obese children, 119 (68.8\%) were overweight, 50 (28.9\%) with first-degree obesity and four (2.3\%) with second-degree obesity. Among overweight children and those with first-degree obesity, there were significantly more girls, while among children with sec-

Table 1. Specific risk factors of metabolic syndrome among obese children according to the degree of obesity

\begin{tabular}{|l|l|l|l|l|}
\hline Risk factor & $\begin{array}{l}\text { Overweight } \\
\mathrm{n}(\%)\end{array}$ & $\begin{array}{l}\text { Degree I obesity } \\
\mathrm{n}(\%)\end{array}$ & $\begin{array}{l}\text { Degree II obesity } \\
\mathrm{n}(\%)\end{array}$ & $\begin{array}{l}\text { Total } \\
\mathrm{N}(\%)\end{array}$ \\
\hline $\begin{array}{l}\text { BMI } \\
\text { Waist size } \\
>\text { P90 } \\
\text { Blood pressure } \\
>130 / 85 \mathrm{~mm} \mathrm{Hg} \\
\text { Cholesterol } \\
>5.06\end{array}$ & $119(68.7)$ & $50(28.9)$ & $4(2.3)$ & $173(100.0)$ \\
& $117(98.3)$ & $49(98.0)$ & $4(100.0)$ & $170(98.2)$ \\
$\begin{array}{l}\text { HDL cholesterol } \\
<1.03 \mathrm{mmol} / \mathrm{L}\end{array}$ & - & $21(42.0)$ & $1(25.0)$ & $61(35.2)$ \\
$\begin{array}{l}\text { LDL cholesterol } \\
>3.4 \mathrm{mmol} / \mathrm{L} \\
\text { Triglycerides } \\
>1.7 \text { mmol/L }\end{array}$ & $24(20.2)$ & $5(10.0)$ & - & $17(9.8)$ \\
\hline
\end{tabular}

$\mathrm{BMI}=$ body mass index; waist size $>\mathrm{P} 90=$ waist size more than $90^{\text {th }}$ percentile; $\mathrm{HDL}=$ high-density lipoprotein; $\mathrm{LDL}$ = low-density lipoprotein 
Table 2. Glycemia, insulin and C-peptide during oral glucose tolerance test (OGTT), baseline (0) and 2 hours post-load (2 b) in 21 obese children

\begin{tabular}{|l|l|l|l|l|l|l|}
\hline No. & Sex & $\begin{array}{l}\text { Obesity } \\
\text { degree }\end{array}$ & Obese child & $\begin{array}{l}\text { Glycemia } \\
0 ; 2 \mathrm{~h}\end{array}$ & $\begin{array}{l}\text { Insulin } \\
0 ; 2 \mathrm{~h}\end{array}$ & $\begin{array}{l}\text { C-peptide } \\
0\end{array}$ \\
\hline 1 & M & I & D.I. & $5.1 ; 6.5$ & 14.088 .9 & 0.75 \\
2 & F & I & Lj.Lj. & 5.35 .7 & 14.824 .1 & 0.71 \\
3 & M & I & B.B. & 4.46 .8 & 10.5172 .9 & 0.63 \\
4 & M & I & L.M. & 5.83 .5 & 13.377 .4 & 0.71 \\
5 & M & I & P.I. & 5.46 .4 & 9.459 .1 & 0.74 \\
6 & F & I & M.E. & 5.27 .1 & 10.177 .9 & 0.6 \\
7 & F & I & S.M. & 4.56 .3 & 11.864 .4 & 0.85 \\
8 & F & I & L.T. & 5.36 .4 & 11.568 .9 & 0.79 \\
9 & M & I & R.A. & 5.36 .4 & 18.269 .7 & 0.73 \\
10 & F & I & S.I. & 5.67 .1 & 17.168 .9 & 0.74 \\
11 & M & I & A.M. & 5.47 .8 & 16.979 .8 & 0.71 \\
12 & M & II & A.N. & 5.06 .9 & 14.095 .9 & 0.91 \\
13 & F & II & K.M. & 5.77 .7 & 21.1116 .6 & 1.20 \\
14 & F & II & J.E. & 5.87 .3 & 26.7180 .5 & 0.83 \\
15 & F & II & Z.B. & 5.66 .2 & 18.179 .8 & 0.74 \\
16 & F & II & J.I. & 5.36 .9 & 17.9104 .2 & 0.79 \\
17 & F & II & I.A. & 6.17 .9 & 17.4128 .3 & 0.62 \\
18 & M & III & Z.V. & 5.09 .4 & 9.459 .1 & 0.74 \\
19 & F & III & G.T. & 5.18 .6 & 11.0206 .9 & 0.58 \\
20 & M & III & I.M. & 5.49 .7 & 16.1253 .0 & 0.9 \\
21 & M & III & P.L. & 4.87 .1 & 15.091 .5 & 0.7 \\
\hline
\end{tabular}

ond-degree obesity the number of girls and boys was equal. Increased waist circumference was recorded in 170 (93.3\%), elevated blood pressure in 61 (35.3\%), increased cholesterol in 17 (9.8\%), increased triglycerides in $14(8.1 \%)$ and high LDL cholesterol levels in 38 (21.9\%) study children. The value of LDL cholesterol was found to rise with the degree of obesity. Lower levels of HDL cholesterol were found in five $(23.8 \%)$ of 21 obese children. The percentage of children with low HDL cholesterol levels $(<1.03 \mathrm{mmol} / \mathrm{L})$ increased with the degree of obesity ( 0 in overweight children, $33.3 \%$ in children with first-degree obesity and $75 \%$ in those with second-degree obesity) (Table 1).

In 21 obese children, glycemia and insulin were monitored in fasting state and 2 hours post-loading with glucose, and C-peptide in fasting state; their results are shown in Table 2. Fasting glycemia <6.1 $\mathrm{mmol} / \mathrm{L}$ was recorded in $20(95.2 \%)$ children, impaired fasting glucose in one $(4.76 \%)$ female child with first-degree obesity, and IGT in four (19.04\%) children including three children with second-degree obesity and one with first-degree obesity. During OGTT, none of them had the values of fasting glycemia and 2 hours post-load typical for diabetes.

High baseline insulin level was recorded in one (4.76\%) child with first-degree obesity. Baseline Cpeptide levels were within the normal limits in all study children.

Monitoring the mean values of glycemia and insulin during OGTT revealed some significant results (Table 3). The values of glycemia and insulin 2 hours post-load rose with the degree of obesity. There were no significant differences in the values of $\mathrm{C}$-peptide among the children according to the degree of obesity.

\section{Discussion}

In the present study, we monitored the prevalence of certain factors of metabolic syndrome, possible dis- 
Table 3. Most relevant results obtained by monitoring pooled (mean) glycemia (Gl) and insulin (Ins) levels during oral glucose tolerance test ( 0 , baseline; 2,2 h post-load)

\begin{tabular}{|l|l|l|l|l|l|l|l|l|l|}
\hline & \multicolumn{3}{|l|}{ Minimum } & \multicolumn{2}{l|}{ Maximum } & Mean & \multicolumn{2}{l|}{ Standard deviation } \\
\hline Degree of obesity & $\mathrm{n}$ & G1 0 & G1 2 & G1 0 & G1 2 & G1 0 & G1 2 & G1 0 & G1 2 \\
\hline I & 11 & 4.4 & 3.5 & 5.8 & 7.8 & 5.21 & 6.36 & 0.421 & 1.096 \\
II & 6 & 5.0 & 6.2 & 6.1 & 7.9 & 5.58 & 7.15 & 0.387 & 0.619 \\
III & 4 & 4.8 & 7.1 & 5.4 & 9.7 & 5.08 & 8.7 & 0.25 & 1.163 \\
\hline
\end{tabular}

\begin{tabular}{|l|l|l|l|l|l|l|l|l|l|}
\hline & \multicolumn{3}{|l|}{ Minimum } & \multicolumn{2}{l|}{ Maximum } & \multicolumn{2}{l|}{ Mean } & \multicolumn{2}{l|}{ Standard deviation } \\
\hline Degree of obesity & $\mathrm{n}$ & Ins 0 & Ins 2 & Ins 0 & Ins 2 & Ins 0 & Ins 2 & Ins 0 & Ins 2 \\
\hline I & 11 & 9.4 & 24.1 & 18.2 & 172.9 & 13.42 & 77.46 & 3.046 & 35.787 \\
II & 6 & 14.0 & 79.8 & 26.7 & 180.5 & 19.2 & 117.5 & 4.314 & 35.075 \\
III & 4 & 9.4 & 59.1 & 16.1 & 253 & 12.875 & 156.6 & 3.189 & 92.203 \\
\hline
\end{tabular}

orders of glycemia, insulin and C-peptide levels during OGTT in obese children. Out of all the factors of metabolic syndrome among obese children, the most frequent were the increase of waist size above $90^{\text {th }}$ percentile (P90) (98.2\%), high blood pressure (35.2\%), lowered HDL (23.8\%) and high LDL cholesterol (21.0\%). Besides the predominant increase in waist size, it means that every third obese child had high blood pressure and every fifth child had high LDL cholesterol. High total cholesterol (9.8\%) and triglycerides $(8.1 \%)$ were found in a significantly smaller percentage of obese children.

Waist obesity is the first factor of metabolic syndrome in childhood according to the order of manifestation, then inducing a chain of metabolic processes that result in metabolic syndrome. Layers of adipose tissue on the stomach lead to higher excretion of fatty acids in liver circulation and higher fat in the blood, also serving as a source of different hormones (adipokines) that are involved in the development of insulin resistance. In this study, it was indicated by high LDL cholesterol. Obesity is accompanied by reduction in the number and sensitivity of specific insulin receptors on target cells. Cells become insensitive to insulin and a relatively small amount of glucose is dissolved, the level of blood glucose rises, which further stimulates the pancreas to higher secretion of insulin. On the contrary, weight reduction associated with limited calorie input and physical activity improves insulin sensitivity $^{7}$. Insulin resistance is defined as a response to lower than normal insulin that leads to hyperinsulinemia in an attempt to maintain normal glucose lev- els. Therefore, hyperinsulinemia due to the higher beta-cell secretion is one of the main accompanying features, along with insulin resistance. The main characteristics of insulin resistance are poor inhibition of gluconeogenesis, disturbed glucose uptake in the muscles and poor inhibition of adipose tissue lipolysis ${ }^{8}$.

The results of our survey indicated the state of insulin resistance to be accompanied by higher insulin secretion during OGTT. At 2 hours post-load, hyperinsulinemia increased significantly with the degree of obesity. In obese children, insulin resistance and hyperinsulinemia are accompanied by changes in glucose tolerance during OGTT, expressed as impaired fasting glucose and IGT. IGT during OGTT, with high values of glycemia, but still not so high to be characterized as diabetes, was present in $19.04 \%$ of obese children. The second possible characteristic of metabolic syndrome is impaired fasting glucose; in our study, no case of diabetes was recorded during OGTT. This means that there was no reduction of plasma insulin due to beta-cell decomposition, and no hyperglycemia and lipid disorder indicating metabolic syndrome progression to diabetes. Anyhow, it is a slow process that will not manifest in childhood but remains as a risk for development of T2DM in obese children in adulthood. In our country, this fact was pointed out by Bojović as early as $1980^{11}$. As for the question whether IGT or impaired fasting glucose occurs first in the development of metabolic syndrome, we consider that IGT occurs first ${ }^{12}$. This conclusion is drawn from the fact that IGT is present at a much higher percentage in obese children than impaired fasting glucose. $\mathrm{Nu}^{-}$ 
merous epidemiological studies in the world $\mathrm{d}^{13-16}$ and two in Montenegro ${ }^{17}$ show that obesity in childhood takes on epidemic proportions. Taking into account this fact, it is necessary to determine the prevalence of metabolic syndrome among obese children, as it is obviously on increase ${ }^{18}$. It should be noted that the prevalence of metabolic syndrome, and especially of some specific elements of metabolic syndrome, increases with the degree of obesity ${ }^{19}$.

The existing program and the mode of evaluating nutritional status on systematic examinations of children do not enable setting the diagnosis of early disorders of overweight and degree of obesity. With the new approach, it should be possible to enter data on BMI during systematic examinations of children.

\section{Conclusion}

The presence of risk factors for cardiovascular diseases and metabolic disorders, especially carbohydrates and fat, is very high in the population of obese children. Therefore, early recognition of genetic factors and environmental factors, as well as of combinations of risk factors for metabolic syndrome among obese children and adolescents is of utmost importance. To this end, there is a need for monitoring of lipid status and glucose tolerance among obese children, especially those with waist type of obesity.

It is necessary to determine and monitor BMI once a year among children and adolescents so as to identify obesity on time and prevent its harmful influence. This imposes the need to change the current method of assessment of nutritional status of children during systematic examinations, as well as registration and follow up of the children with overweight and pronounced obesity.

In addition to the necessary preventive measures to reduce obesity as a risk factor that can lead to serious metabolic disorders, early detection of the presence of individual or associated parameters of the metabolic syndrome in obese children is necessary.

\section{References}

1. International Obesity Task Force - a new worldwide definition of the metabolic syndrome. Consensus from the International Diabetes Federation, Berlin; 2005.

2. Cook S, Weitzman M, Auinger P. Prevalence of metabolic syndrome phenotype in adolescents: findings from the Third $\mathrm{Na}^{-}$ tional Health Nutrition Examination Survey, 1988-1994. Arch Pediatr Adolesc Med. 2003;157821-7, doi:10.1001/archpedi.157.8.821.

3. Reaven GM. Syndrome X. In: Degroot I, Jameson LJ, Larry J, et al., eds. Endocrinology. Philadelphia: WB Saunders, 2002; 954-8.

4. Defronzo RA, Ferrannini E. Insulin resistance: a multifaceted syndrome responsible for NIDDM, obesity, hypertension, dyslipidemia, and atherosclerotic cardiovascular disease. Diabetes Care. 1991;14(3):173-94, doi: 10.2337/diacare.14.3.173

5. Vague J. La diffférenciacion sexuelle, facteur déterminant des formes de l'obésité. Presse Med. 1947;30:339-40. (in French)

6. Kaplan NM. The deadly quartet. Upper-body obesity, glucose intolerance, hypertriglyceridaemia and hypertension. Arch Intern Med. 1989;149:1514-20.

7. De Ferranti SD, Gauvreau K, Davis SL. Prevalence of the metabolic syndrome in American adolescents - findings from Third National and Nutrition Examination Survey. Circulation. 2004;110:2494-7, doi: 10.1161/01.CIR.0000145117. 40114.C7

8. Bojović B. Epidemiology of children obesity in school age in SR Montenegro with special research of its influence on metabolism of carbohydrates. Doctoral dissertation, University of Novi Sad, Novi Sad; 1980:280-300.

9. Kimm S, Obarzanek E. Childhood obesity: a new pandemic of the new millennium. Pediatrics. 2002;110(5):1003-7.

10. Amer P. Differences in lipolysis between human subcutaneous and adipose tissues. Ann Med. 1975;27:435-8.

11. Bojović B, Kavarić J. The disturbance of metabolism of carbohydrates among children of school age in Montenegro, with special retrospective view on some risk factors. Titograd: UZZDCG;1998.

12. Greenfield JR, Campbell LF. Insulin resistance and obesity. Clin Dermatol. 2004;22:289-95.

13. Nelms BC. Childhood obesity: taking on the issue. J Pediatr Health Care. 2001;15(2):47-8, doi:10.1067/mph.2001.113405.

14. Ogden C, Flegal K, Carroll M, et al. Prevalence and trends in overweight among US children and adolescents, 1999-2000. JAMA.2002;288(14):1728-32, doi:10.1001/jama.288.14.1728.

15. Eckel RH, Grundy SM, Yimmet PS. The metabolic syndrome. Lancet. 2005;365:1415-28, doi: 10.1016/S0140-6736(05) 66378-7.

16. American Diabetes Association. Relationship between CVD risk and the metabolic syndrome. Diabetes Care. 2005;28(9): 2289-304.

17. Martinac M, Pehar D, Karlović D, Babić D, Marčinko D, Jakovljević M. Metabolic syndrome, activity of the hypothalamic-pituitary-adrenal axis and inflammatory mediators in depressive disorder. Acta Clin Croat. 2014;53:55-71.

18. Sondike BS. Overweight and obesity. In: Sarafoglou K, Hoffmann FG, Roth SK, eds. Pediatric Endocrinology and Inborn Errors of Metabolism. New York: McGraw-Hill; 2008. p. 275-90.

19. Majkić Singh N. Medical Biochemistry. Belgrade: Društvo medicinskih biohemičara Srbije; 1994:171-227. 
Sažetak

\section{UČESTALOST KARDIOVASKULARNIH ČIMBENIKA RIZIKA U PRETILE DJECE}

\section{Rakočević i V. Rakočević}

Cilj studije bio je odrediti učestalost pojedinačnih čimbenika metaboličkog sindroma kod pretile djece ispitujući krvni tlak, lipidni status, poremećaje glikoregulacije, parametre inzulinske osjetljivosti i lučenja. Istraživanje je provedeno u obliku poprečne studije. Analizirani su rezultati pretile djece u dobi od 7 do 16 godina u Kliničkom Centru Crne Gore u razdoblju od 2011. do 2015. godine. Od 173 djece s povišenim indeksom tjelesne mase, $119(68,8 \%)$ ih je imalo prekomjernu težinu, $50(28,9 \%) 1$. stupanj pretilosti i četvoro djece (2,3\%) 2. stupanj pretilosti. Povišen krvni tlak imalo je $35,2 \%$, povišene vrijednosti kolesterola 9,8\% i povišene vrijednosti triglicerida 8,09\% pretile djece. Tijekom oralnog opterećenja glukozom poremećenu glikemiju natašte imalo je $4,76 \%$, a poremećenu toleranciju glukoze $19,04 \%$ pretile djece. Povišene vrijednosti insulinemije dva sata poslije opterećenja glukozom imalo je 35\% pretile djece. Zastupljenost čimbenika rizika za kardiovaskularne bolesti i metaboličke poremećaje, naročito ugljikohidrata i masti, u populaciji pretile djece je veoma visoka. To nameće potrebu izmjene sadašnjega načina procjene uhranjenosti djece pri sistematskim pregledima, kao i registriranja i praćenja djece s prekomjernom tjelesnom težinom i izraženom pretilosti.

Ključne riječi: Metabolički sindrom X; Pretila djeca; Rizični čimbenici; Učestalost 